\title{
Impacts of glacial retreat on benthic iron supply using a radium/thorium disequilibrium approach
}

\author{
AMBER ANNETT ${ }^{1}$, PINGHE CAI ${ }^{2}$, JAMES WILLIAMS ${ }^{3}$, \\ DIPANJU BURAGOHAIN ${ }^{1}$, RHIANNON JONES ${ }^{1}$, OLIVER \\ G. FLANAGAN ${ }^{1}$, MEHUL VORA ${ }^{4}$, NADESCHA \\ ZWERSCHKE $^{5}$, CHESTER SANDS $^{5}$, DAVID BARNES ${ }^{5}$, \\ JAMES SCOURSE $^{6}$, XIANGMING SHI ${ }^{7}$, QINGQUAN \\ $\mathrm{HONG}^{2}$, LIN WEI ${ }^{2}$ AND XUEYING SHI ${ }^{2}$ \\ ${ }^{1}$ University of Southampton \\ ${ }^{2}$ Xiamen University \\ ${ }^{3}$ Cardiff University \\ ${ }^{4}$ Rutgers, The State University of New Jersey \\ ${ }^{5}$ British Antarctic Survey \\ ${ }^{6}$ Exeter University \\ ${ }^{7}$ University of Connecticut \\ Presenting Author: a.l.annett@soton.ac.uk
}

The Southern Ocean has absorbed $\sim 30 \%$ of anthropogenic carbon dioxide emissions to date. Biological components of this uptake are limited chiefly by scarcity of iron (Fe), and in the lowdust environment of the Southern Ocean the main sources of $\mathrm{Fe}$ are shelf sediments and glacial inputs. Along the Western Antarctic Peninsula (WAP) over $87 \%$ of glaciers are retreating, with delivery of glacial $\mathrm{Fe}$ to surface waters expected to increase. Drivers of sedimentary Fe supply are poorly constrained, but high rates of bacterial remineralisation and resuspension of $\mathrm{Fe}$ rich shallow sediments play a major role in sustaining the high $\mathrm{Fe}$ inventory of deep shelf waters. Fine particulate material in meltwater can scavenge $\mathrm{Fe}$, efficiently shuttling $\mathrm{Fe}$ to the sediment. However, increased delivery of particulates can negatively affect benthic organisms via mass accumulation rate and high turbidity. Consequently, changes in composition, bioturbation and bioirrigation of the sediment have the potential to affect remineralisation rates, as well as speciation and bioavailability of $\mathrm{Fe}$. We used the novel ${ }^{224} \mathrm{Ra} /{ }^{228} \mathrm{Th}$ disequilibrium approach to assess how deglaciation affects sedimentary Fe release at three rapidly retreating WAP glacier fronts WAP.

Porewater profiles of $\mathrm{Fe}$ (and other bioactive metals and nutrients) were combined with Ra flux derived from the deficit of soluble ${ }^{224} \mathrm{Ra}$ with respect to its rate of production by parent isotope ${ }^{228} \mathrm{Th}$ in surface sediments. While Fe profiles reflected local geological composition and oxygen consumption, $\mathrm{Ra} / \mathrm{Th}$ derived $\mathrm{Fe}$ fluxes revealed a consistent trend of reduced $\mathrm{Fe}$ flux with glacier front distance, suggesting that continued glacial retreat may reduce Fe supply. Similar trends were seen in fluxes of other metals (manganese, lead) but with greater overall range and variability between sites. These results are discussed in the context of sediment characteristics, benthic assemblages, and macronutrient profiles to predict changes in biogeochemical cycling as climate change continues. 